\title{
MODEL OF AXIOLOGICAL DIMENSION RISK MANAGEMENT
}

\author{
Ewa KULIŃSKA \\ Opole University of Technology, Faculty of Production Engineering and Logistics, Poland \\ e-mail: e.kulinska@po.opole.pl
}

\begin{abstract}
It was on the basis of the obtained results that identify the key prerequisites for the integration of the management of logistics processes, management of the value creation process, and risk management that the methodological basis for the construction of the axiological dimension of the risk management (ADRM) model of logistics processes was determined. By taking into account the contribution of individual concepts to the new research area, its essence was defined as an integrated, structured instrumentation aimed at the identification and implementation of logistics processes supporting creation of the value added as well as the identification and elimination of risk factors disturbing the process of the value creation for internal and external customers. The base for the ADRM concept of logistics processes is the use of the potential being inherent in synergistic effects which are obtained by using prerequisites for the integration of the management of logistics processes, of value creation and risk management as the key determinants of the value creation.
\end{abstract}

Keywords: logistics processes, value added, risk management, axiological dimension of the risk management (ADRM) in logistics processes.

\section{$1 \quad$ Introduction}

The aim of this paper is to present a new research area of the management science that was formed at the junction of three categories: value-added management, risk management, and management of logistics processes in the form of the axiological dimension of the risk management (ADRM) in logistics processes.

In the opinion of the author, the risk management in logistics processes has a significant impact on increasing the value created in main processes of a production company both for customers as well as for the company itself. The comprehensive identification and quantification of the processes in terms of creation of the value added is a base for identifying risk factors and, hence, a base for the implementation of risk management in logistics processes. Therefore, there should be a possibility to build a parameterization model for the ADRM in logistics processes with the use of the cause-effect and structural relationships, which are so characteristic for the essence of operations of production companies.

To create a model for ADRM in logistic processes, the assumptions and elements of modern concepts of management, especially strategic management, were used. A special role in the light of presented issues was attributed to synergistic effects emerging as a consequence of integrating these ideas.

These are own studies as a result of the ADRM model of logistics processes enabling parameterization of the value added and its changes because of risk factors in logistics processes which are the subject of the paper.

\section{Determination of sources and the origin of the research}

While going back to the origin, it has to be said that the ADRM concept of logistics processes was largely based on the basic assumptions referring to the paradigm of the process organization, which is perceived as a key determinant for the identification of key logistics processes related to the creation of value added. The process orientation sets the rules for operation of a company, of which the primary goal is to produce and offer the highest value for customers and for the company itself. The proposed structure and characteristics of individual components of the ADRM concept of logistics processes are based on the assumptions of the process organization concept. 
The process approach determines the process of value creation in the context of integration of management of logistics processes, management of value creation, and risk management.

The research on organizations oriented at processes carried out were first performed by Hammer, Champy (1993) and Davenport (1993). Their concepts are different in dynamics, in the way and the time of redesigning vertical structures into horizontal ones. However, the concept of an organization oriented at flows carried out has gained vast popularity so far. Numerous publications and studies in this area show that the concept of a process organization is not a fad but an idea, thanks to companies that are able to achieve higher efficiency and value added, which is translated directly into profit or loss.

What important is contributed by the process orientation of an organization? As it was shown by Rummler and Brache (2000, pp.31-36), a process-oriented organization shows the flow of resources, their transformation, suppliers, customers, and, in particular, the effect of the process, which is the final product meeting customers' expectations. Moreover, it shows places at which the effect of work of one position is transferred to the next one for further transformation, that is, the points, which should be the core of the management, because they are the most important ones from the point of view of raising efficiency of the process and translating it directly into value created.

From the point of view of this paper, the advantages of the process approach are very important and provide the basis for analysis of logistics processes. However, their priority is manifested mainly in the possibility of identification of any risk factors that may interfere with logistics processes, hindering or preventing from achieving final results that are objectives for which they have been introduced. From the point of view of these deliberations, the most important objectives are creation of the value for customers and creation of the value added for a company.

The ability to create value for a customer and a company is a subject of interest of many researchers in the area of management science. Value, as a key axiological category within this discipline, is treated as a decision criterion, as a measure for the evalua- tion of activities of companies, and as an objective, after which companies aspire.

The next category important from the point of view of the subject under discussion is the risk management. The author's interest in this field dates back to the year 2000. The main reason for the work in this field is the belief of the author that the studies carried out by scientific staff at universities should be translated into solutions that could be applied by Polish companies in order to reduce risk factors. The cooperation in this field is growing but is still insufficient. On one hand, there are many computer programs that solve problems already solved by entrepreneurs; on the other hand, the hermetic environment of companies put limits on access to data and information on current problems arising from lack of or improper risk management.

As it is evidenced by ongoing studies and content of the literature in the field of the management science, the growing problems with keeping competitive position are forcing companies to look for new solutions to ensure their existence in the market. This is one of the main reasons behind seeking for complementarity areas of the well-known management concepts. The application of integrated concepts increases the likelihood to succeed in this respect, so it seems to be justified to try to combine concepts complementary because of their key attributes that are important for the operations of companies.

There are many examples in the literature for the integration of different modern management concepts such as the concept of the marketing and logistics management (Makarski, 2010) and the concept of qualitative and logistics management (Długosz, 2000); there are also examples for the combination of logistics with reengineering, benchmarking, and other modern management concepts.

The ADRM concept of logistics processes is based on three key categories: management of value added, risk management, and management of logistics processes. They appoint first axiological perspectives:

1) the universality of structural (logistics) consideration of processes,

2) the need for risk assessment for the implementation of processes, 
3) value added, as a major category (criterion) for the risk assessment

together with the consequences for the theory and practice of management of manufacturing companies.

The first axiological perspective is associated with the universality of the structural attitude towards processes executed by a manufacturing company and it results already from the analysis of their constituent elements. There is a possibility to identify a managing entity in every process. This entity has the authority and necessary skills, the managing style adequate to the situation, and proper management methods. The way of its influence is determined by the adopted development plan of the organization: mission, vision, strategy, and objectives resulting from them. These are people acting as a "subordinate" element that are the subject of the management. The managed entity (the receiver of the decision) recognizes the power of the managing entity, has necessary skills, and reports aspirations resulting from the desire and the need to meet diverse needs to the organization. The managed entity has influence on resources of the organization so as to achieve the state expected by the management. Decision and information feedbacks in the relationship of the managed and managing entity are based on the determined, bilateral exchange of information and unilateral transmission of the managerial decisions.

The structural perception of processes is also consistent with the structural-functional theory. The supporters of this theory, among others, A. Comte and $\mathrm{H}$. Spencer, believed that society as a whole was composed of mutually dependent components, which enabled functioning and development of the entire population. All the parts are equally important and form an indivisible whole. It has its analogies on the ground of the management of processes.

A process is a set of related components that transform input resources into output resources having value for a customer. The process approach shows that logistics should be focused on courses of specific activities. Such an approach makes it easier to optimize a business as a whole, because the boundaries among departments, which obstruct communication, are replaced by boundaries among processes. As a result, the outcome of the process is becoming a superior objective and after all, these are processes and their outcomes, which are the source of delivering products required by customers. Logistic processes support functioning of the management system and ensure its effectiveness and efficiency. They include activities and actions associated with preparation of infrastructure for basic processes, management, information systems, transport, storage, accounting, and financial reporting and controlling.

Coordination of all activities in an enterprise is also within logistic processes. The ultimate goal of the coordination is to obtain the unanimity in the accomplishment of the task, which these activities are components of. The key to the coordination is the insight into the internal structure of the executors and the determination of their objectives. Logistic processes appear when there is a need to coordinate the main processes executed in a manufacturing company.

The second axiological perspective determines the need to assess the risk of the process execution. The risk management in an enterprise is a way to create value added in a turbulent environment. It is in response to the current market situation that there is a growing need in organizations to develop an efficient and effective approach to the risk management and optimization.

There is a need to invest time and financial resources to implement solutions improving risk management of process execution. The presence of risk factors in logistics processes causes their instability. Continuous changes in internal and external conditions of functioning of processes cause that the risk is constantly evolving. It is in these circumstances that the development of strategies to improve risk management gives a chance to develop a relative stability of processes through

1) knowledge (recognition) of all possible risk factors that may occur in the processes executed,

2) possibility to predict, which risk factors are present and with what intensity, in which effects they result and how to counteract them,

3) possibility to develop preventive measures for the identified risk groups, 
4) possibility of better understanding and measuring risks, strategic objectives, and thus narrowing the control area.

The risk management in enterprises was largely seen only as a tool for eliminating or reducing risk factors. Nowadays, more and more companies start to realize that it is too narrow use of this tool. The most important issue is to understand that risk does not always mean something negative for an organization but it should also be perceived as a potentially positive factor. It is by accepting and managing risk that enterprises are able to measure and assess possible benefits resulting from taking specific challenges. They are also able to maximize profits and increase value for their customers by reducing certain risk factors and taking advantage of other ones.

Based on the research conducted by the author, the conclusion that there is a lack of companies willing to take challenges in Poland can be drawn. There are also only a few companies that manage risk. The minimization of risk factors is manifested mainly in a play-safe approach toward management.

The third axiological perspective is associated with value added as a key category and a key criterion for assessing risk. The basis for the ADMR parameterization of logistics processes is the value for a customer and the value added for the given company.

The category of the value added in the economic science is defined as a difference between the value of expenditure incurred for purchasing materials necessary for manufacturing goods and the revenue from their sale obtained by the company. On the other hand, it is in the management science, although there are different opinions on this issue in the literature, that creation of value added of a company is defined as the primary objective of the operations of the company. These are also the survival and development of a company, generating profits in the long run, maximization of the capital profitability in a long term, and so on, which are considered to be the primary objectives of a company (cf. Marcinowska, 2000, p.18; Banaszyk, 1998). Such an approach requires a proper way of looking at company resources and management.

The analysis of the considerable literature on the role, nature, and ways of creating value relates mainly to products supplied by companies and not to the way of functioning of a company as a whole. The value added is very often beyond conscious control of a company, because there is no full description of the mechanisms creating value added. In the concepts well known from the literature, value added is a faint (very difficult to measure) efficiency and competitiveness indicator of an enterprise. It is more or less an intended effect of a specific operation way of an organization.

More and more often in the works of various Polish practitioners and theoreticians, as B. Wawrzyniak, Z. Martyniak, K. Obłój, [...] or fereign as M.E. Porter, P.F. Drucker, R.S. Kaplan, D.P. Norton [...], the attention is drawn to the fact that the traditional concepts, methods, and techniques of management of modern organizations are primarily based on systems of financial ratios that seem to be ineffective today (Platonoff, Sysko-Romańczuk, 2004). Hence, the category of the value added (as a cause and effect of certain management decisions) should be treated multidimensional and beyond financial ratios should be included in the analysis. At the same time, the approach of the value creation chain (as a sum of processes) in a company does not fully explain the mechanism of its creation and thus the mechanism of value-added creation (Platonoff, Sysko-Romanczuk, 2004).

The use of value added as a criterion for the ADMR parameterization of logistics processes requires identification of the recipients of the value. These are internal and external customers of the manufacturing company.

The systematically measured value added provides information on the pace and direction of development of the organization and enables conscious management.

\section{The ADMR Model of Logistics Processes}

Given the high degree of complexity of the structure of logistics processes, risk management, and issues related to creation of value added as well as the extent of the data that can be obtained through research without direct participation in the process, it was the modeling approach used by S. Shlaer, S.J. Mellor' that was used for modeling. 
From the point of view of ADMR of logistics processes, the most important is to identify objects, which are subjected to modeling, that is, to identify its domain. The complexity mentioned above may also raise doubts and cause that inappropriate objects will be included in the domain in future. It is also very important to place the ADMR of logistics processes beside other strategies used to manage manufacturing companies. It was in the search for technical description standards that studies enabling their description were carried out.

The domain of the ADRM of logistics processes covers the logistics processes that, because of their supporting nature, enable the main business processes to create value added together with specific risk factors (relevant, (typical) for logistics processes), which (if they appear) cause disturbance in the flow and thus a change (mostly a negative one) in the value added. The value added is considered in economic terms.

The domain does not include the business processes that are not logistics processes. The domain does not include the risk factors that do not relate to logistics processes directly or indirectly. The domain does not include non-economic aspects of value-added creation.
The axiological dimension of the risk management of logistics processes falls within the scope of the strategic and operational management of a manufacturing company.

While taking into account the steps of creation of the ADRM of logistics processes, they must include

1) definition of the basis for the integration and interpretation of the ADMR of logistics processes,

2) determination of the integration area,

3) determination of the impact of the process orientation on the integration of the management of logistics processes, the integration of management of creation of value added, and risk management,

4) determination of the basis for appointing the model domain among the processes that are determined by the risk management that secures creation of the value added for customers and the company,

5) determination of the structure of ADRM of logistics processes,

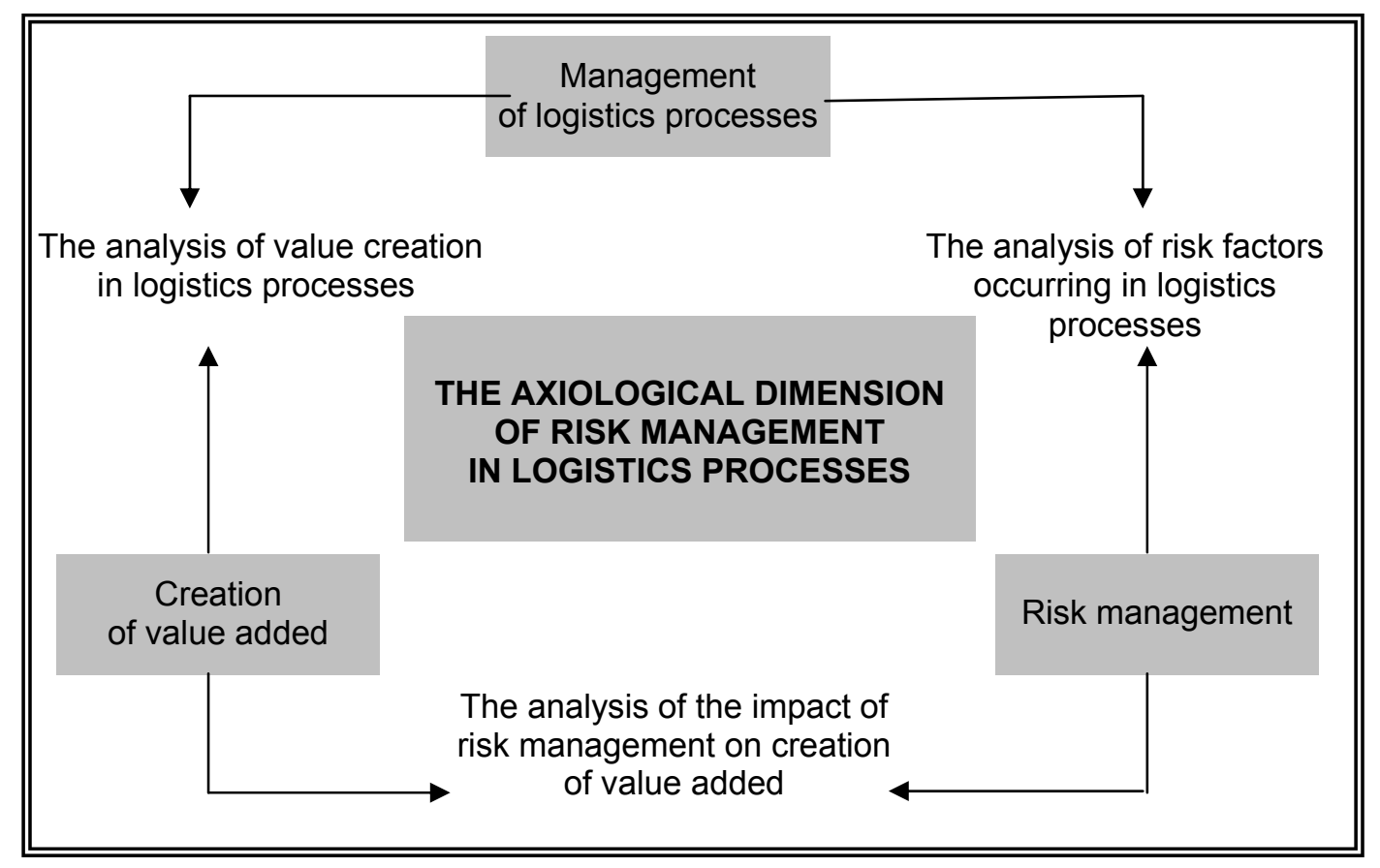

Figure 1. The basis for the identification and integration of the component concepts for the ADRM of logistics processes (source: own study) 
6) search for the rationale behind the integration of objectives of the management of logistics processes, objectives of the management of the value creation, and objectives of the risk management in the form of integrated ADRM objectives of logistics processes,

7) search for the rationale behind the integration among objectives, instruments, and results in the ADRM concept of logistics processes,

8) determination of the structure of the value creation in the ADRM chain of logistics processes.

The result of the analysis carried out is the development of a model that covers the basic assumptions of the ADRM of logistics processes within the scope of the determination of the basis for the integration of its key categories (Fig. 1).

The rationale behind the integration of management of logistics processes, management of value added creation, and risk management is reflected in the model concept of the ADRM of logistics processes.
The concept of the ADRM of logistics processes determines the creation of value added for customers and companies. It is not a simple combination of concepts but a multidimensional result of the integration of concepts, functions, and levels of management of the dynamic structure of logistics processes along with the risk factors occurring in them toward the increase in the creation of the value added for customers and for the company.

The ADRM of logistics processes puts the emphasis on the market areas of the execution of the logistics processes combining the market dimension and flow dimension of the processes of creation of the value added. The key area for the integration of management of logistics processes, management of valueadded creation, and risk management in the ADRM of logistics processes is the market, perceived as a subjective and an objective starting point for operations of an enterprise (cf. Fig. 2).

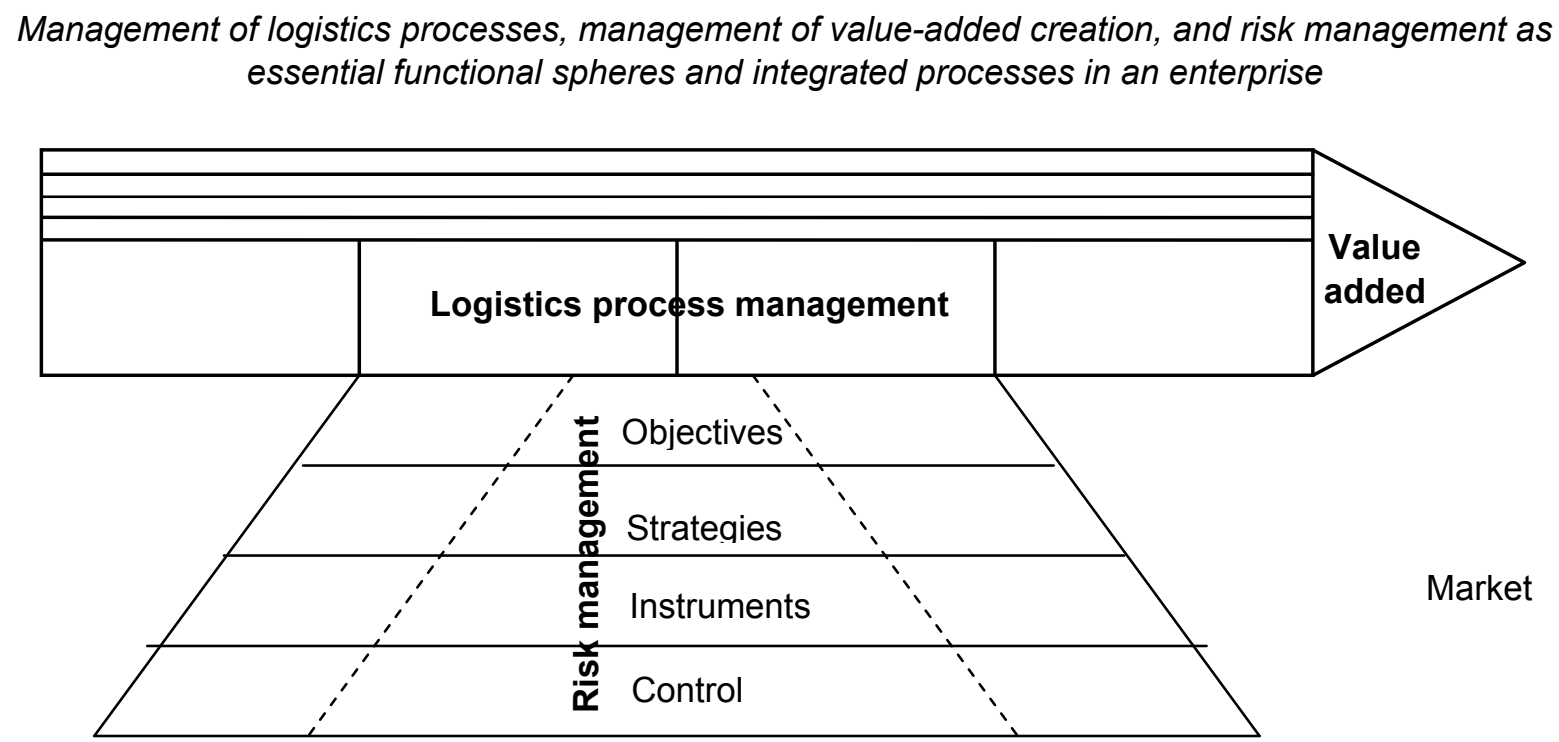

Figure 2. Determination of the integration area for the ADRM of logistics processes (source: own study)

The market, as the integration area, determines to a large extent the way of formulation of the base assumptions for the modeled ADMR concept of logistics processes. Fulfillment of the market requirements/expectations and own aspirations must be taken into account at all levels of the organization.
Therefore, the ADRM concept of logistics processes was largely based on the assumptions referring to the paradigm of the process organization, which is perceived as a key determinant for the identification of key logistics processes related to creation of value added (Fig. 3). 


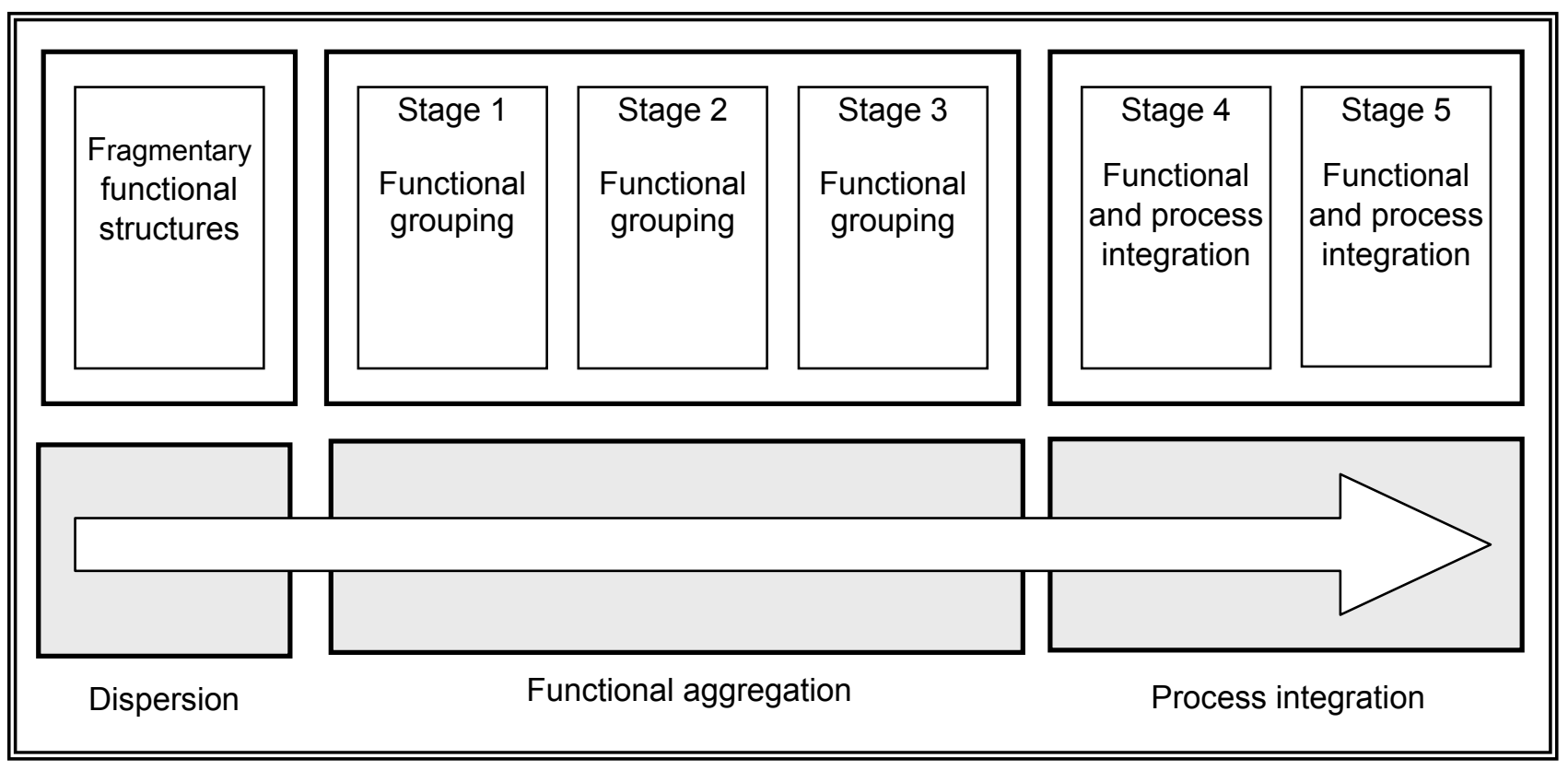

Figure 3. Evolution of the paradigm of organization of logistics processes management (source: own study on the basis of: Bowersox, Closs, 1996)

The process orientation sets the frames for the operation of a company, of which the primary goal is to produce and offer the highest value for customers and for the company itself. The proposal of the structure and the characteristics of individual components of the ADRM of logistics processes are based on their perception as key determinants of the value creation in the context of the integration of the management of logistics processes, management of value-added creation, and risk management.

Therefore, the structure and the content of further considerations are largely determined by the individual aspects associated with the rationale behind the integration of the categories mentioned above in the form of the ADRM of logistics processes.

Both the studies carried out and the analysis of the literature justify the focus on logistics processes. Logistics processes are among the ones creating the highest costs in manufacturing companies. Reduction of the time needed for the introduction of new products to the market is so large that the only one thing left for the companies is constant streamlining and strengthening the value creation processes through the reduction of the costs of logistics processes. The creation of the value for a customer in the sense of a set of additional benefits and usefulness is also related to the improvement of logistics processes. The ways of the product use, customer satisfaction, convenience, comfort, and solutions of customers' problems are also dependent on logistics processes. It is to a large extent that companies realize market value and benefits, which create value for a customer as well as value added for companies, through logistics processes.

Therefore, it can be concluded that the role and importance of the logistics processes that contribute or may contribute to the increase in the value offered to customers and thus to the increase in the value added realized by the company is increasing disproportionately.

An important prerequisite for the increase in the value added is the continuous improvement of processes. A number of options and potential in this respect are associated with the concept of risk management. Planning, organizing, implementing, and controlling the disruption of logistics processes contribute to the creation of a higher level of value for a customer and higher value added for the company (Kulińska, 2009).

The risk management process can be interpreted as an appropriate transformation process, whose objective is to achieve the highest value added. 


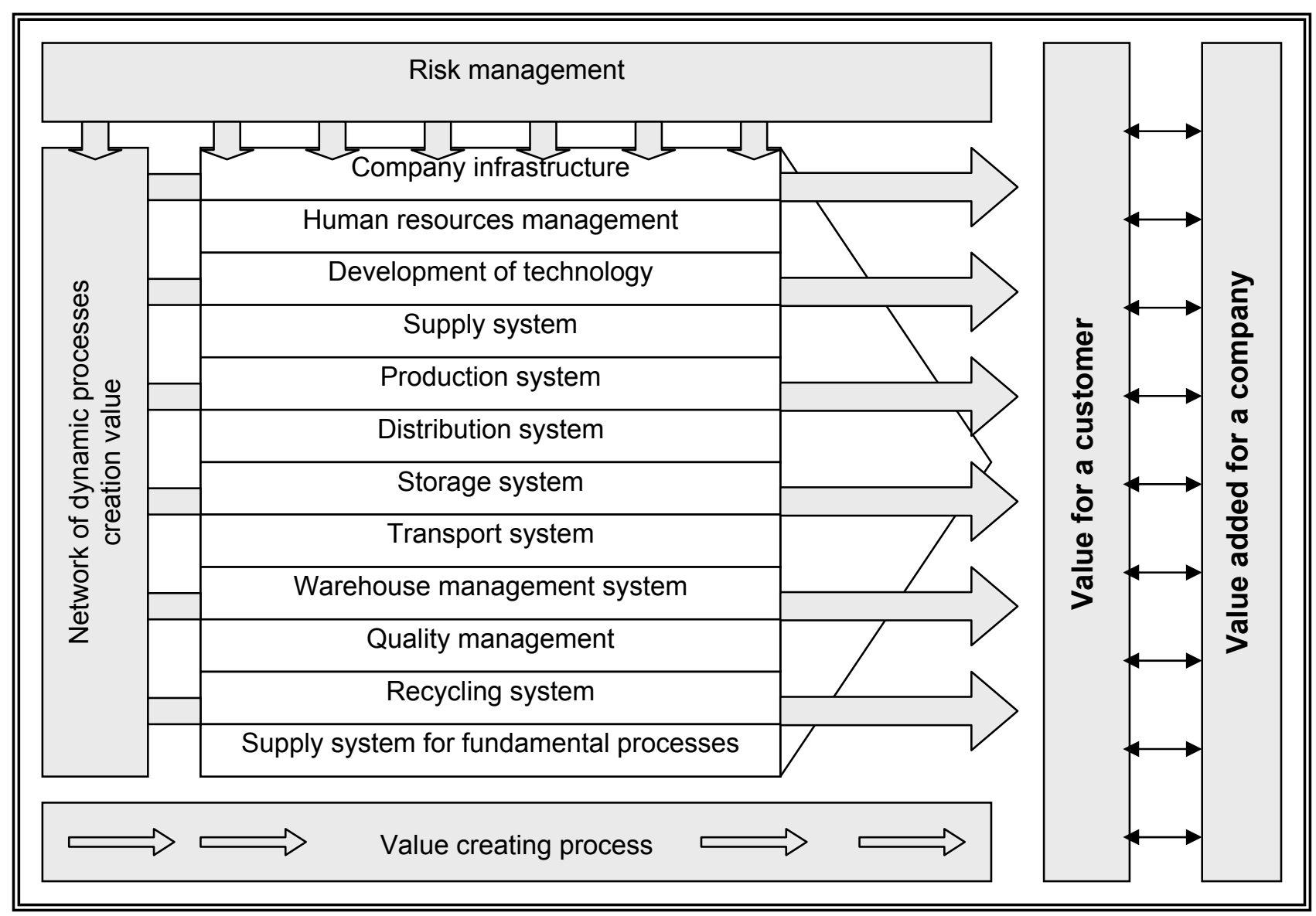

Figure 4. The course of dynamic processes that is determined by risk management supporting and securing the creation of value for a customer and the company

(source: own study)

Therefore, it is in the case of the ADRM of logistics processes that the course of dynamic processes is determined by the risk management that supports and secures the creation of the value for a customer and the value added for the company (see Fig. 4).

The most important factors and requirements that support, justify, and thus determine and stimulate the integration of the management of logistics processes, management of value-added creation, and risk management in the form of the ADMR of logistics processes include:

- the dynamic changes in the market, which are manifested in differentiation of needs and preferences of customers, changes in the structure of the market, differentiation of products, increase in competitiveness in meeting the increasingly sophisticated customer expectations with respect to additional benefits and utilities related to the purchase of products,
- europeanization and globalization of markets,

- the need to optimize the cost structure because of the increasing intensity of competition processes,

- creation and development of new sale channels,

- aspiration for the use of synergy effects within the scope of the system of value creation for all market participants,

- development of technologies, particularly in the IT sector, development of network dependencies,

- increase in the importance of modern management concepts in shaping management strategies,

- increase in the importance of risk management in respect of ongoing business processes.

These factors necessitate searching for new management concepts such as the ADRM of logistics processes, which could enable flexible adjustment to the market needs. 
Management of logistics processes, risk management, and management of value creation are characterized by their dissimilarity in the sense of traditional (functional) perception of the company's management process. Therefore, there is a need to transform assumptions toward the integrated concept of the ADRM of logistics processes.

The concepts mentioned earlier are based on certain standards in the process of implementation of actions and functioning of the enterprise in the market. With regard to the logistics processes, the basis is the organization of the flow sphere of a manufacturing company, which connects the main flow areas, that is, supply, production, and distribution.

Within the scope of the risk management, the starting point is the identification and elimination/minimization of the impact and likelihood of occurrence of risk factors.

Within the scope of the management of value creation, it is customer along with the entire structure and scope of his or her needs, desires, requirements, expectations, tastes, preferences, as well as demand understood as demonstrated willingness to buy certain goods supported by the acquisition possibility that are the basis for the concept.

Each of the categories mentioned earlier is characterized by a formal, precisely defined own structure, which can be presented on the background of fundamental phases (components) of business management processes.

According to R.W. Griffin, creation of a strategy requires knowledge of mission, strategic, tactical, and operational goals as well as strategic, tactical, and operational plans ${ }^{1}$. Each new concept must take into account an appropriate structure already on the modeling stage so that it is possible to implement it in the business strategy.

The analysis of the structure of the management of logistics processes, risk management, and management of value creation shows that there is a number of similarities associated with the essence, structure, content, and trends determining and stimulating their development. It allows for the determina-

\footnotetext{
${ }^{1}$ cf. R.W. Griffin, Podstawy zarządzania organizacjami (Fundamentals of organization management), Wydawnictwa Naukowe PWN, Warsaw 2002, pp. 198-253.
}

tion of possibilities inherent in the integrated use of the concepts mentioned earlier in the form of the ADRM of logistics processes. This is because it creates additional opportunities for obtaining higher value for customers and increasing the created value added.

The structure of the modeled concept becomes a part of the normative, strategic, operational, and functional management levels. It creates a possibility to fulfill requirements and strategic and development plans of an organization and thus gives a chance for its adaptation.

The structure of the ADRM model of logistics processes at the normative level shown in Fig. 5 includes the integration of analytical, diagnostic, and forecasting procedures. It is primarily reflected in the reformulation of the mission of the enterprise, which consists of directional, superior guidelines for planning and implementation procedures.

At the next level, there is the integration of procedures and operations that covers the strategic stage directly affecting the development of plans and programs at operating level. The last level consists of control and verification activities. The diagram in Fig. 5 is the basis for an attempt to define the structure and the scope of the management according to the ADRM concept of logistics processes.

The structure of the model also takes into account the identification of the objectives at strategic, operational, and executive levels. The strategic objectives determine the formulation and development of the company strategy including the ADRM of logistics processes.

The process of formulating integrated objectives of the ADRM of logistics processes is carried out through setting partial objectives, management of logistics processes, management of creation and realization of value added, and risk management.

The general objectives are the basis for the formulation and development of the integrated strategy of the ADRM of logistics processes, for the development and application of the complementary instrumentation, as well as for the implementation and realization of the overall strategy. The ADRM model of logistics processes from Fig. 5 was expanded in the area concerning objectives in Fig. 6. 


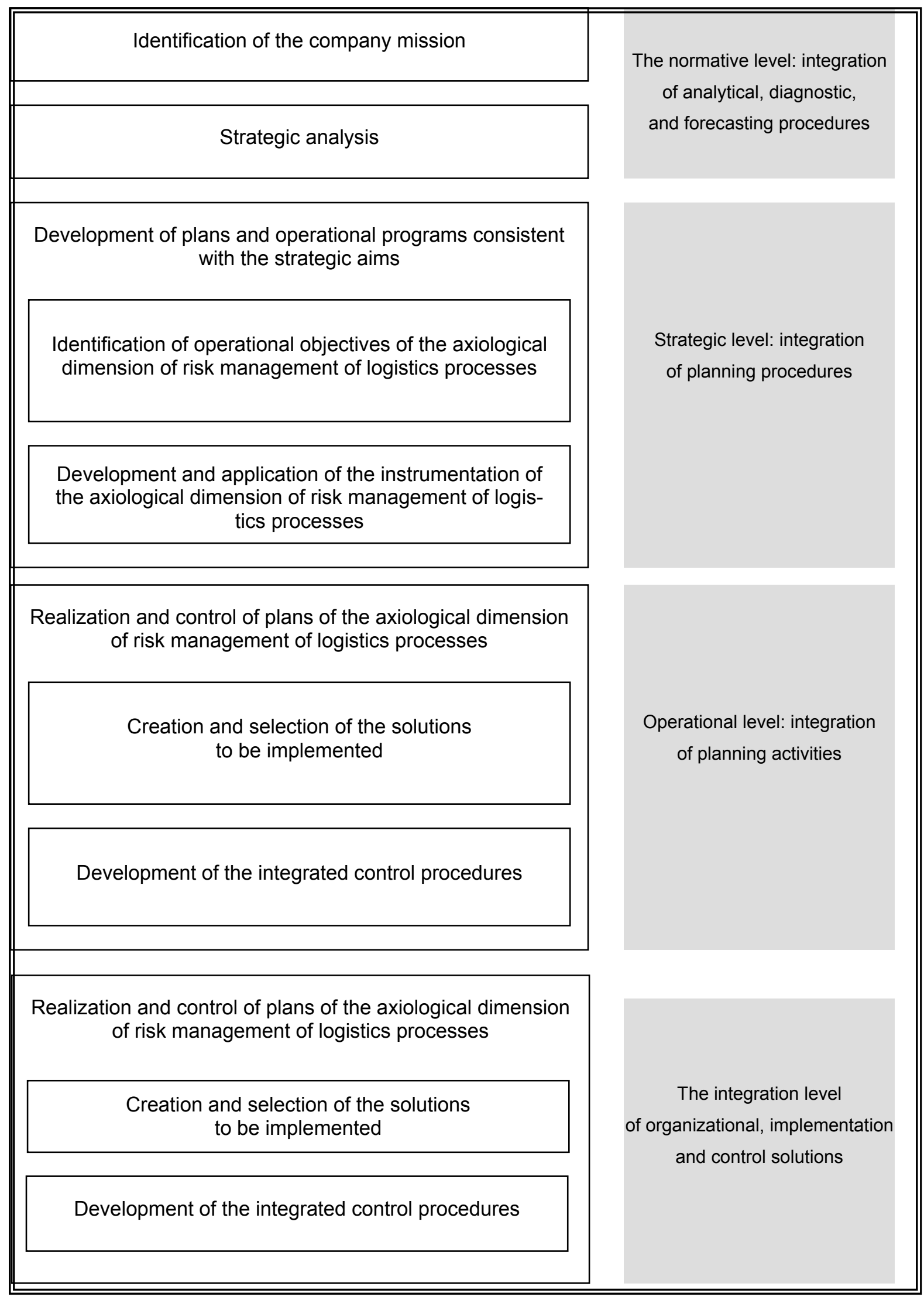

Figure 5. The structure of the ADRM model of logistics processes (source: own study) 
Objectives of the logistics process management

The total satisfaction of customer market needs through offering relevant products with appropriate information, at appropriate place and time, in appropriate quantity and quality, as well as at the appropriate level and structure of costs.

Development of the optimal (desired) relationship between the logistic support for supplies and total logistics costs.

Obtaining the profit, which allows the company for development and further economic activity.

\section{Objectives of the manage- ment of value-added crea-} tion:

The increase in the value for the company through appropriate development and satisfying demand as well as increasing the market share.

The increase in the value for customers through creating, recognizing, and satisfying needs and desires of customers; maximization of utility (benefits) offered to customers; and the permanent adaptation of company's activities to the changing market (customer) requirements
Risk management objectives:

Maximization of the likelihood to achieve objectives of the organization.

Minimization of the effects of disadvantageous actions, events, and circumstances.

Maximization of the risk of potential gains, which can be obtained by the organization.

\section{General (integrated) objectives of the axiological dimension of risk management}

\section{of logistics processes}

- Maintaining an appropriate level of profit in a strategic dimension

- Strengthening the position as well as obtaining and maintaining the competitive edge on the market

- Coordination and realization of company's objectives from the point of view of risk management and maximization of created value added

- Adjustment of the flow of goods and information to wishes and preferences of customers

- Implementation of the concept of the ADMR of logistics processes as a directed transformation of goods and value (benefits) along the chain (system) of creation and supply of value.

- Identification and creation of new potential supporting achievement of the market success

\section{Formulation and development of an integrated strategy with the ADRM} of logistics processes

\section{Development and application of the instrumentation of the ADRM of logistics processes}

\section{Implementation and realization of the integrated strategy}

Figure 6. Integration of the objectives of the ADRM of logistics processes

(source: own study) 


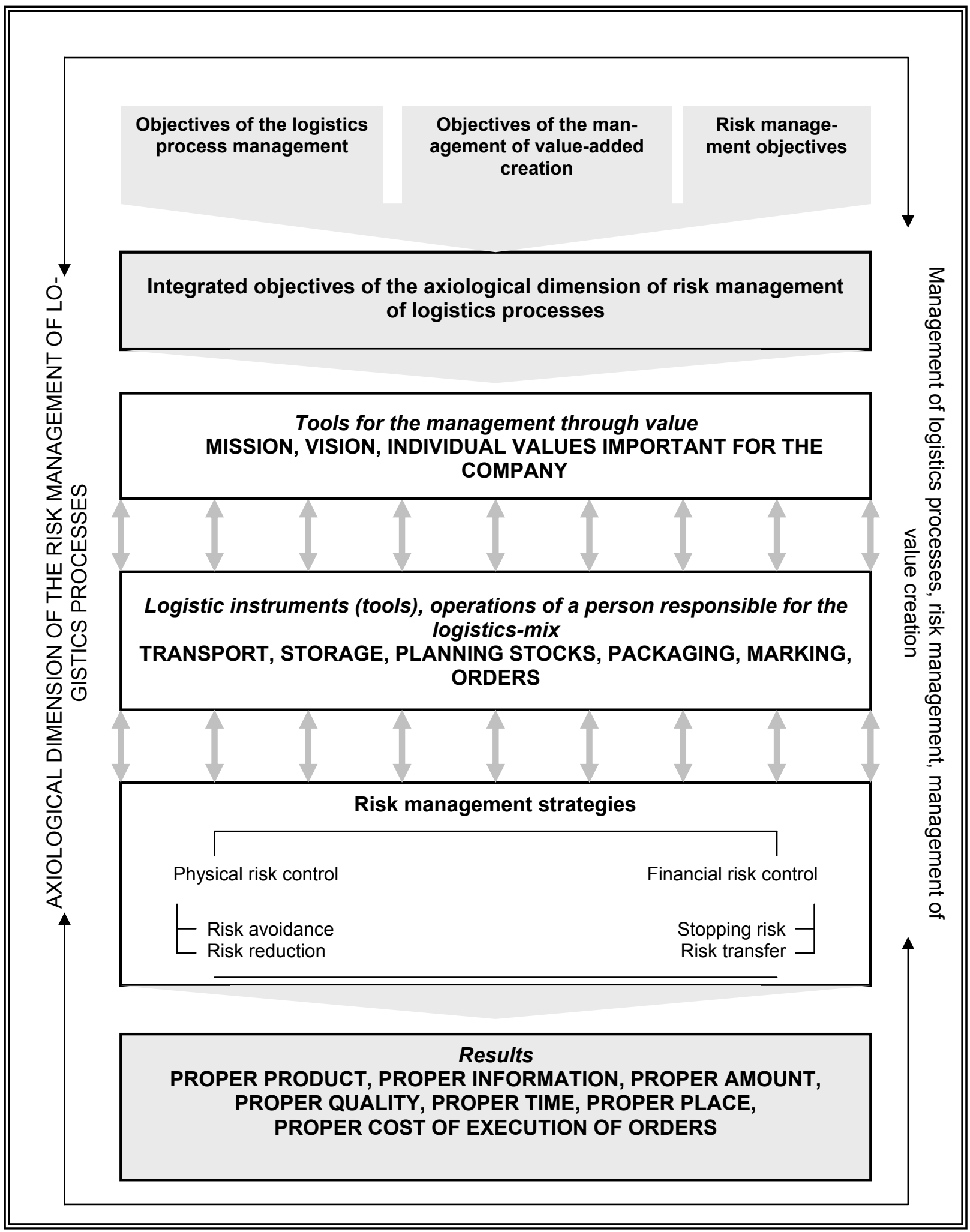

Figure 7. Relations among operational objectives, instruments, and management outcome according to the concept of the axiological dimension of the risk management of logistics processes

(source: own study) 
The structure of the ADRM model of logistics processes draws attention not only to the identification of individual objectives within the scope of the management of logistics processes, management of value creation, and risk management, or only to the objectives of the concept of the ADRM of logistics processes, but it is also based on the objectives adopted by the company during the development and implementation of its integrated strategy. It emphasizes the need for verification and evaluation of realization of the assumptions using instruments and control tools from the point of view of the results obtained.

The objectives are subjected to the verification from the point of view of created value in the form of the 7P concept: the proper product, proper information, proper quantity, proper quality, proper time, proper place, and proper cost of execution.

The relationship among assumed objectives and obtained results is an important criterion for justification and assessment of the integration of the management of logistics processes, management of value creation, and risk management in the ADRM model of logistics processes.

It is in Fig. 7 that the main relationships among tools and strategies of the ADRM of logistics processes are shown, the choice and implementation of which result from the individual objectives of the given company and the results that may arise from their implementation.

\section{The essence of the ADMR of logistics processes}

The rationale behind the need for the development of the ADRM model of logistics processes and, at the same, its strength is the existence of the relationship with the crucial category of the market economy, which is the market itself.

The concept of the management of value creation has strictly market dimension; according to the idea of the ADRM of logistics processes, these are supporting the value creation through comprehensive risk management of logistics processes, in particular in the light of increasing total benefits and utilities offered on the market, increasing efficiency of creation of new solutions for realization of supply and distribution processes that have a good chance to support manufacturing companies by achieving and maintaining the competitive edge on the market.

To sum up the current considerations, the ADRM of logistics processes should be defined as an integrated, structured instrumentation aimed at the identification and implementation of logistics processes supporting creation of the value added as well as identification and elimination of risk factors disturbing the process of the value creation for internal and external customers.

The base is the use of the potential being inherent in synergistic effects that are obtained by using prerequisites for the integration of the management of logistics processes, management of value creation, and risk management as the key determinants of the value added creation.

The potential inherent in the synergetic effects become more evident after including the ADRM of logistics processes in the concept of the value creation chain.

The value chain, not only in terms of the cause and effect, is not only about a chain of successive steps but about the chain in the meaning of dependencies and relationships among integrated concepts. Each of them contributes some specific elements to the ADRM of logistics processes, which would probably have "greater freed" beyond the concept. However, the integration puts some limits defined by the nature of the ADRM of logistics processes giving the possibility of achieving synergy effects in exchange.

Obtaining synergy effects depends, therefore, on a specific interaction that is determined by the integration of the management of logistics processes, management of value-added creation, and risk management within the scope of the ADRM of logistics processes (see Fig. 8).

Fig. 8 is based on M. Porter's model, which was enriched with components specific to logistics and risk management. The value chain includes, inter alia, a set of processes that takes into account logistics processes in the supporting area. 


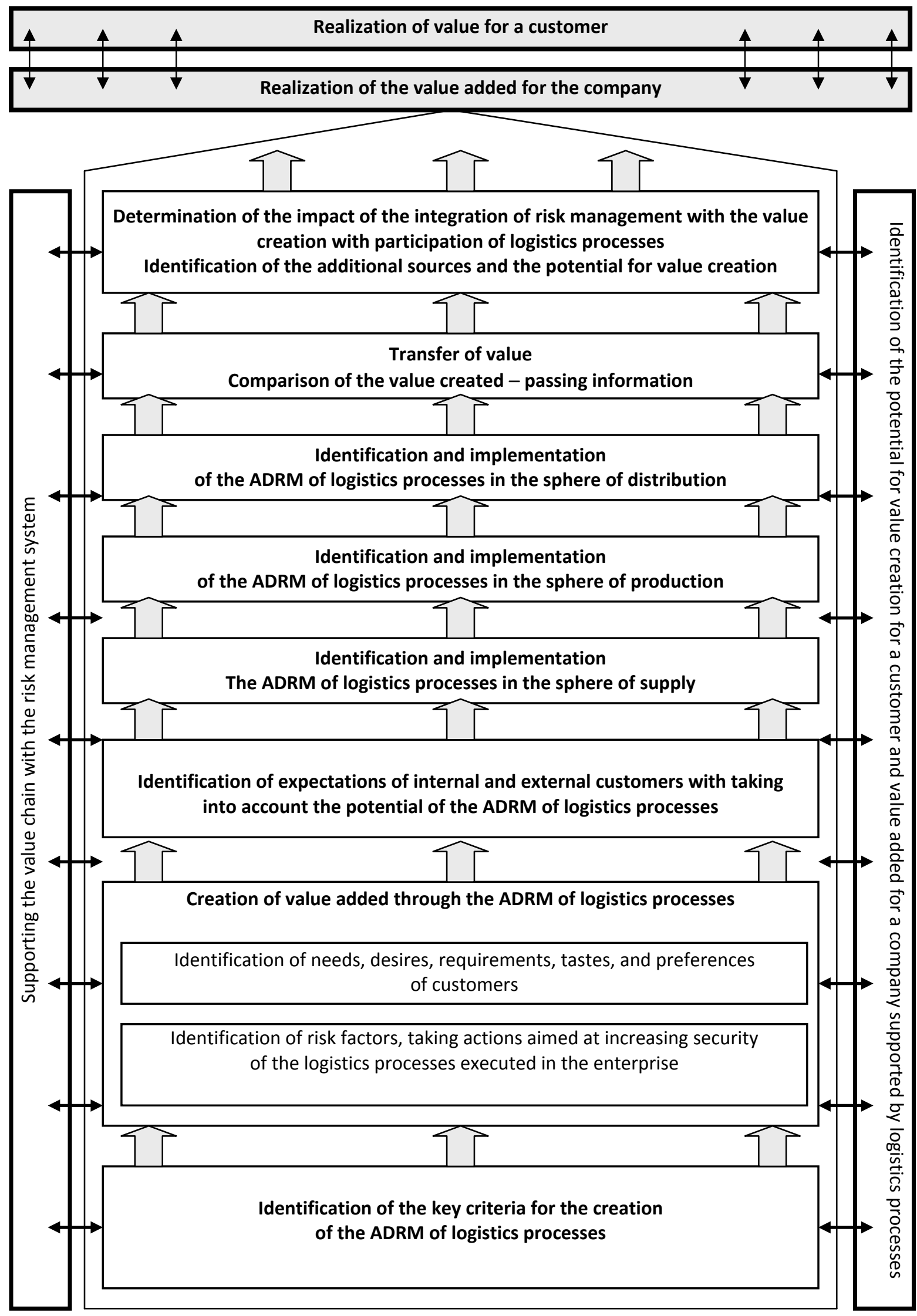

Figure 8. The structure of the ADRM of logistics processes in the structure of the value creation chain (source: own study) 
The support requires reliability, so it is not possible to consider logistics processes as "second-class" processes, and in order to ensure the reliability of the course of main processes, it is needed to make every effort so as that the supporting sphere does not fail.

The value added in the ADRM model of logistics processes is defined as the economic value reflected in the utility of the result of the process. The main types of economic utilities are the form utility, place utility, time utility, and ownership utility (Coyle, Bardi, Langley Jr., 2002). Production activities are assigned to the form utility, marketing activities to the ownership utility, and logistics activities to the place and time utilities.

The results of processes should be available, where they are needed by consumers and at the time when they are needed by them (elements of 7P). The logistics processes support creation of value within the enterprise by enabling physical flow of goods between departments and workstations.

The resulting place utility is realized mainly by means of transport. The realization of the time utility by logistics processes that support main processes in a manufacturing company is reflected in maintaining the proper level of stocks and strategic placement of goods and flow of information (Coyle, Bardi, Langley Jr., 2002).

The risk management is a process closely related to the company's activities and as such forms a part of the structure of the value chain. As a result of its realization, when risk factors appear, it is possible to assess the efficiency and rationality of taken actions and to estimate the level of realization of expectations. It is crucial for the comparison of value added.

\section{Conclusions}

The structure of the ADRM of logistics processes in the structure of the value chain is constructed on the basis of the reference processes. It is on this basis that it may be applied to any company, and while taking into account references to the value chain, it may include different entities operating in the market: suppliers, customers, distributors, dealers, and so on.
The concept of the ADRM of logistics processes provides a basis for further research in the direction of supporting logistics solutions, especially in the field of value creation processes (increasing the total benefits and utilities offered on the market), creation of new solutions for realization of supply and distribution processes, as well as achieving and maintaining long-term competitive edge on the market.

The concept of the ADRM model of logistics processes has a chance to be developed into an integral component of the system of value creation for the entire market and all management processes. However, it requires preparation (selection or development) of the new measurement instrumentation.

\section{$6 \quad$ References}

[1] Banaszyk, P., 1998. Formułowanie celów strategicznych w zarządzaniu polskimi przedsiębiorstwami (Formulation of strategic objectives in the management of Polish companies). Poznań: Akademia Ekonomiczna.

[2] Bowersox, D.J., Closs D.J., 1996. Logistical Management. The Integrated Supply Chain Process. New York: McGraw-Hill Companies.

[3] Coyle, J.J., Bardi, E.J., Langley, Jr. C.J., 2002. Zarządzanie logistyczne (Logistics Management). Warszawa: PWE.

[4] Davenport, T.H., 1993. Process Innovation. Reengineering through Information Technology. Harvard Business School Press.

[5] Długosz, J., 2000. Relacyjno-jakościowa koncepcja logistyki w zarzadzaniu (Relational and quality concept of logistics in management). Poznan: Wyd. AE.

[6] Griffin, R.W., 2002. Podstawy zarządzania organizacjami, (Fundamentals of organizational management). Warsaw: Wyd. Naukowe PWN.

[7] Hammer, M., Champy, J., 1993. Reengineering the Corporation. A Manifesto for Business Revolution. HarperCollins Publishers.

[8] Kulińska, E., 2009. Ryzyko procesów logistycznych $\mathrm{w}$ aspekcie tworzenia wartości dodanej macierz relacji. (Risk of logistics processes in terms of value added - relationship matrix). Logistyka 2/2009, pp.46-47. 
[9] Makarski, S., ed., 2010. Zarządzanie marketingowo-logistyczne w tworzeniu wartości produktu (Marketing and logistics management in creating value of a product). Rzeszów: Wyd. Uniwersytetu Rzeszowskiego.

[10] Marcinowska, M., 2000. Kształtowanie wartości firmy (Creation of a company value). Warszawa: PWN.

[11] Platonoff, A., Sysko-Romańczuk, S., 2004. Wartość dodana w zarządzaniu - próba zdefiniowa- nia i operacjonalizacji pojęcia. (Value added in management - an attempt to define and operationalize the concept). Przeglad Organizacji 9/2004.

[12] Rummler, G.A., Brache, A.P., 2000. Podnoszenie efektywności organizacji. (Increasing efficiency of an organization). Jak zarządzać „białymi plamami“"w strukturze organizacyjnej? (How to manage the "white spots" in the organizational structure?). Warszawa: PWE. 